Saudi Journal of Oral and Dental Research

Abbreviated Key Title: Saudi J Oral Dent Res

ISSN 2518-1300 (Print) |ISSN 2518-1297 (Online)

Scholars Middle East Publishers, Dubai, United Arab Emirates

Journal homepage: https://saudijournals.com

\title{
The Impact of COVID-19 on Quality of Life of Dentists in Health Care Centers in Saudi Arabia
}

Sadiah S Alghamdi ${ }^{1}$, Rahaf A Alghamdi ${ }^{2 *}$

${ }^{1}$ Ministry of health, Jeddah, Saudi Arabia

${ }^{2}$ Al Danna Medical Complex of Dentistry, Riyadh, Saudi Arabia

DOI: 10.36348/sjodr.2021.v06i01.013 $\quad$ | Received: 08.01.2021 | Accepted: 18.01.2021 | Published: 20.01 .2021

*Corresponding author: Rahaf A Alghamdi

\section{Abstract}

Background: The aim of this study is to assess the effectiveness of COVID-19 on quality of life of dentists at health care centers in Saudi Arabia. Material and Methods: This study was conducted for two weeks. Sample was selected randomly and included 300 dentists from different specialty. Questionnaire about demographic data and effect of Covid-19 on quality of life were used. Results: A total of 204 (68\%) of dentists who replied was work in government sector. Their average age ranges from 20 years to 50 years and most of the dentist who answered the questionnaire (45\%) work for more than 10 years of service. The second part about the effect of the virus on the quality of life most of them (93\%) they feel their safety is in risk during working hours. 87\% of the participant dentist they had a symptom of depression and anxiety and $(70 \%)$ of them they worried about being a source of infection for their family. For the dentists who work in private sector $(40 \%)$ of them afraid from lose their job and facing a financial problem. Conclusion: Regarding to the result we found that COVID-19 pandemic had a negative effect on quality of life for the dentist in both sector the government and private.

Keywords: Covid-19* Quality of Life * Dentist.

Copyright ( 2021 The Author(s): This is an open-access article distributed under the terms of the Creative Commons Attribution 4.0 International License (CC BY-NC 4.0) which permits unrestricted use, distribution, and reproduction in any medium for non-commercial use provided the original author and source are credited.

\section{INTRODUCTION}

Covid-19 it is a new type of virus from large family of Coronaviruses that cause illness starting with the common cold symptoms to more severe condition similarly to Middle East Respiratory Syndrome (MERS-CoV) and Severe Acute Respiratory Syndrome (SARS-CoV). First case was reported and discovered at the end of December 2019 in Wuhan, China then it's began to spread out all in the world.

At 2nd of March 2020 Saudi Arabia record the first case. Then in February 27, 2020 Saudi authorities start taking precautionary and preventive measures in all health care fields fighting this virus and limit its spread, including all sectors and ministries in the kingdom [1].

Ministry of Health is the first sector that started to fight against this pandemic disease, so the health care providers are in frontline for limiting the spread of this virus, they did their best efforts to keep the community and people safe $[2,3]$.

By increasing of the infected cases and working for long hours especially with positive cases in a close area this make the health care staff such a physician, dentist and nurse fell that their safety in risk and working under stress $[4,5]$ therefore, we aim in this study to assess the effect of COVID-19 pandemic on quality of life of dentist in health care center in Saudi Arabia.

\section{MATERIAL AND METHOD}

After receiving approval from ethical committee, this study was conducted in December 2020 and included 300 dentists selected randomly from government and private sectors at health care centers in Saudi Arabia.

Inclusion Criteria: Dentist working in a health care centers, age ranging from 20 to 50 years.

Exclusion Criteria: Deficiencies in completing questionnaires.

\section{Data Collection}

In our study we used an online questionnaire sent to the participants through an email and different social media. It was consisting of two sections. 
First, demographic data including age, gender, years of experience and type of sector. The second section was assessed the impact of the pandemic on the quality of dentist life. The answers to these questions were (Agree, Moderately and Disagree).

Completed questionnaires were collected and the data was entered and analyzed using SPSS version 21.

\section{RESULT}

The response rate for this study was (277 out of 300 participants) $92.33 \%$, all of them worked as a dentist in health care center.

Chart 1, 2 \& 3 and Table-1 presents the descriptive data of the participants.

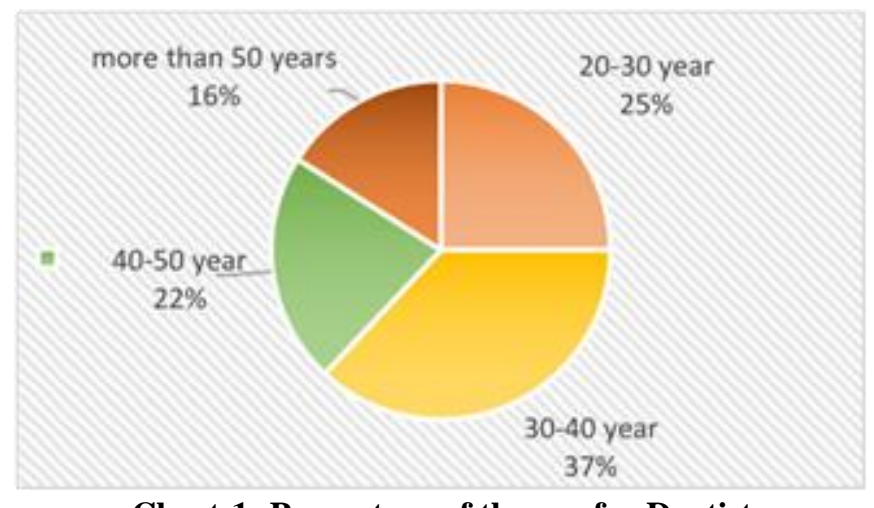

Chart-1: Percentage of the age for Dentist

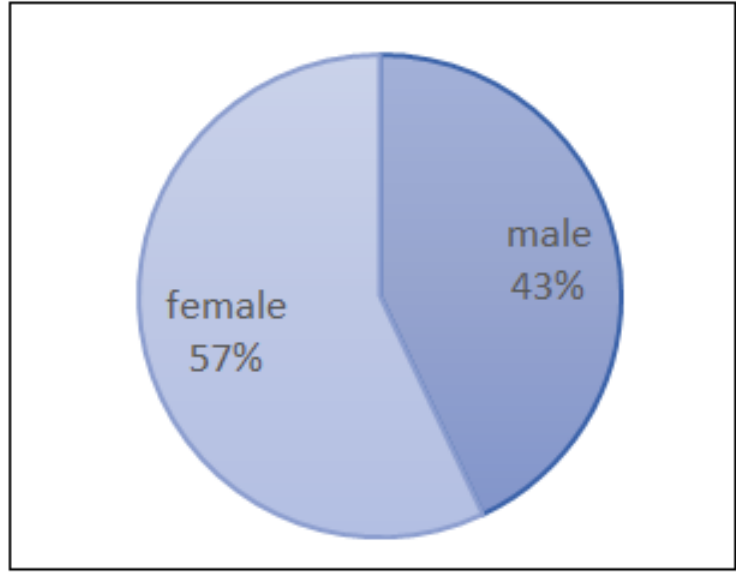

Chart-2: Percentage of gender for Dentist

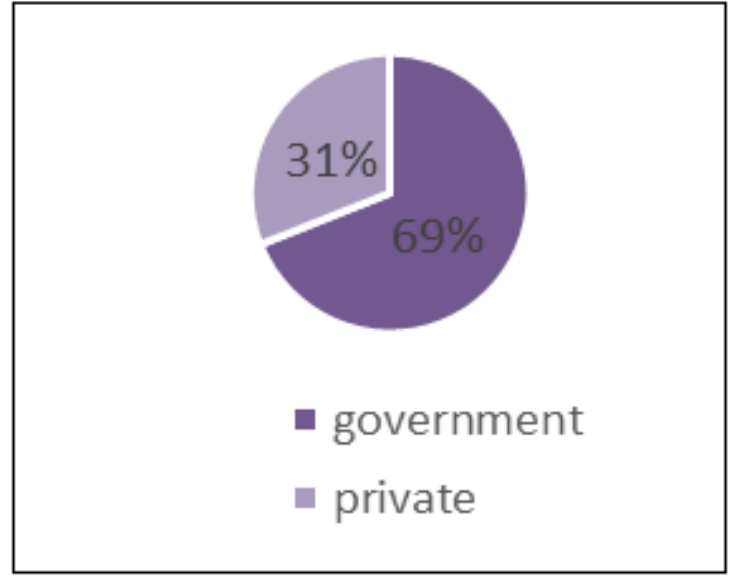

Chart-3: Percentage of type of sector for dentist

Table-1: Distribution of the dentist according to the years of experience.

\begin{tabular}{|l|l|l|l|}
\hline Variable & \# of participant & Percentage \\
\hline \multirow{3}{*}{ Duration of service } & $1-5$ years & 70 & $25 \%$ \\
\cline { 2 - 4 } & $5-10$ years & 77 & $28 \%$ \\
\cline { 2 - 4 } & More than 10 years & 130 & $47 \%$ \\
\hline
\end{tabular}

Regarding to the second part which assessed the effectiveness of covid-19 on their quality of life. (result showed in Fig-1).

Approximately $88 \%$ of participants though that their personal safe is in risk, which leads them to be under stress $(72 \%)$ and start feeling of a depression.

A $61 \%$ of them are thinking that following of the daily news of covid-19 through media is making them to feel an anxiety continuously.
Few numbers of participant $(11 \%)$ said that they are not afraid to lose their job due to pandemic, but the other half are moderately agreed that they face or had a financial issues because of covid-19 (64\%).

Large number of dentists (72\%) had affairs to transmit the virus to their family, where they are equally agreed and disagreed to see and consult a psychiatric physician because of the pandemic. 


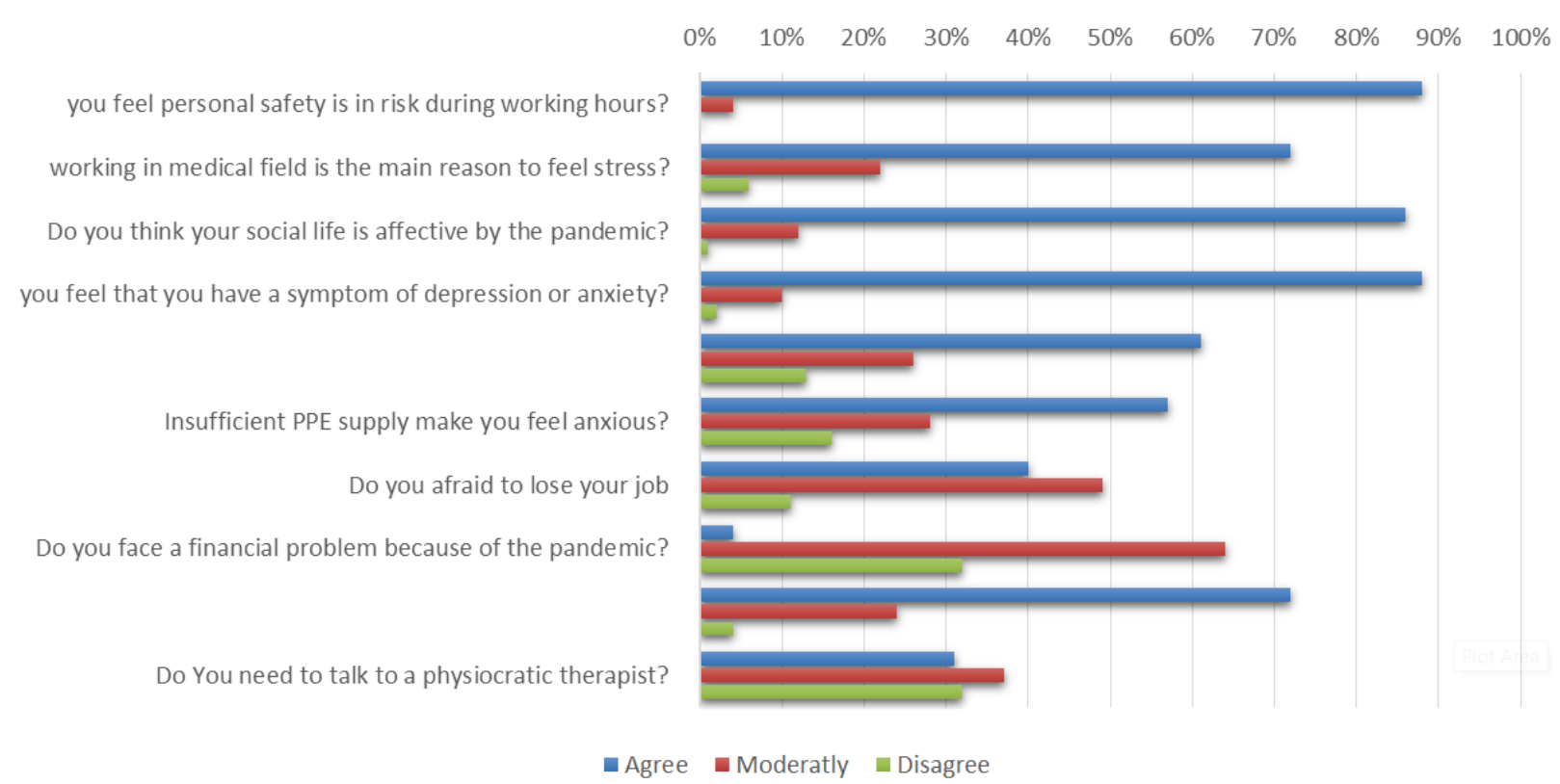

Fig-1: Distributions of the dentists according to the impact of covid-19 on their quality of life

\section{CONCLUSION AND \\ RECOMMENDATIONS}

The result showed us that COVID-19 pandemic disease negatively affected the quality of life of dentist in Saudi Arabia from all aspects, psychologically, socially and financially.

And we recommend that every medical centers have to assist and follow the psychologic and mental health of their staff and start schedule a monthly meeting for all workers to exchange ideas that reduce anxiety and work stress.

\section{Acknowledgment}

We are grateful to the entire participant for their corporation and contributed to the completion of this study.

\section{REFERENCE}

1. Al Jasser, R., Al Sarhan, M., Al Otaibi, D., \& Al Oraini, S. (2020). Awareness Toward COVID-19 Precautions Among Different Levels of Dental Students in King Saud University, Riyadh, Saudi

\section{Arabia. Journal of multidisciplinary} healthcare, 13, 1317.

2. Đogaš, Z., Kalcina, L. L., Dodig, I. P., Demirović, S., Madirazza, K., Valić, M., \& Pecotić, R. (2020). The effect of COVID-19 lockdown on lifestyle and mood in Croatian general population: a crosssectional study. Croatian medical journal, 61(4), 309.

3. Samlani, Z., Lemfadli, Y., Errami, A. A., Oubaha, S., \& Krati, K. (2020). The impact of the COVID19 pandemic on quality of life and well-being in Morocco. Arch Community Med Public Heal. 130-134.

4. Dehkordi, A. H., Gholamzad, S., Myrfendereski, S., \& Dehkordi, A. H. (2020). The Effect of Covid-19 on Anxiety, Quality of Work Life and Fatigue of Health Care Providers in Health Care Centers. 1-14.

5. Ahmadi, H., Ebrahimi, A., \& Ghorbani, F. (2020). The impact of COVID-19 pandemic on dental practice in Iran: a questionnaire-based report. BMC oral health, 20(1), 1-9. 